\title{
Do political or ethnic and historical borders affect values and beliefs more? Some evidence from Central Europe
}

\author{
PÁL CZEGLÉDI* (-)
}

Institute of Economics and World Economy, University of Debrecen, Debrecen, Hungary

Received: January 20, 2021 - Revised manuscript received: April 11, 2021 - Accepted: April 13, 2021

Published online: May 21, 2021

(c) 2021 The Author(s)

\section{ABSTRACT}

The paper uses data from the World Values Survey and the European Values Study on individuals in Hungary and its neighbouring countries to examine the effects of political borders on different beliefs, as opposed to that of ethnic differences or historical borders. The focus on Hungary and its neighbours is explained by the fact that parts of the Hungarian ethno-linguistic community can be found in all these countries, which makes it possible to separate the effect of culture from that of the current political community. By applying a cultural gravity model which is concerned with the differences in beliefs between all possible pairs of individuals in the sample, the paper finds that out of five areas of beliefs, it is the beliefs regarding work, markets, and democracy whose differences are robustly affected by political borders, giving some support to the approach which argues that values are shaped through the dialogue occurring within a political community.*

\section{KEYWORDS}

culture, ethnicity, central europe, hungary

\section{JEL CODES}

A13, B53, P48

\footnotetext{
*Corresponding author. E-mail: czegledi.pal@econ.unideb.hu
} 


\section{INTRODUCTION}

It is now more or less accepted among economists that 'culture matters', by which they mean that countries have different economic outcomes because they have different values and beliefs. But why do countries have different values and beliefs? Is it because different countries have different ethno-linguistic groups which have different values and beliefs? Or, is it because these values are shaped by the discussion within the political community (a country), which leads its members to have similar values and beliefs? This paper is meant to provide some insights to better understand this question by focussing on Hungary and its neighbouring countries.

There are several reasons why Hungary, Serbia, Romania, and Slovakia might be interesting places to consider for an empirical investigation of differences in values and beliefs. The main reason is that (current and historical) political, religious, and ethnic borders do not coincide with each other in this area. The current political borders are relatively new (about 100 years old), and there are substantial Hungarian minorities in all the other three countries. In addition to the current political borders, the border of the former Habsburg Empire (Austria-Hungary), whose significance for present-day beliefs has been shown (Becker et al. 2016; Grosjean 2011), and that of the Kingdom of Hungary, goes through Serbia and Romania. Religious differences are also present in the region as Eastern and Western Christianity, including Protestantism and Catholicism are all represented.

The paper is concerned with the survey results used by economists to quantify values and beliefs. The main question is whether people living in the same country have more similar beliefs even after accounting for their ethnicity, religion, country, and some other individual characteristics. This same-country effect can be meaningfully searched for among the countries mentioned because people belonging to the same culture can be found in more than two countries. This same-country effect is then understood as signifying a certain level of importance in terms of the debates occurring within a polity in the influence it has in shaping the beliefs of its participants.

The reason why such an analysis of the belief distance has something to add to the debate on the economic importance of culture will be explained in Section 2. I will also argue that the 'discussion approach' of political economy (Levy - Peart 2020) combined with some 'Austrian' insights into culture gives different answers to the question as to how and why ethno-linguistic and historical communities and their values and beliefs are related.

The hypothesis I draw from this latter approach will be tested with quantitative evidence on beliefs with the help of a 'cultural gravity model' (Grosjean 2011), with belief distances as dependent variables in the regressions. Belief distances are calculated from the World Values Survey - European Values Study (EVS 2011; WVS 2015) for several beliefs that are usually used in the 'culture and institutions' literature (Beugelsdijk et al. 2019). The empirical model, the data, and the main results, according to which borders matter for values and beliefs even after controlling for their possibly deep determinants, will be presented in Sections 3 and 4, and some broader conclusions in Section 5 . 


\section{LITERATURE REVIEW: WHY DIFFERENT 'VALUES AND BELIEFS'?}

In the brief literature review that follows I will confine myself only to considering the question ${ }^{1}$ : Is culture as understood by economists, which refers to a set of values and beliefs, a characteristic of a political or an ethnic and historical community? I will discuss the mainstream view (Section 2.1) and what may be called the 'discussion approach' (Section 2.2), and argue that East Central Europe is an interesting place to consider for insights on this question (Section 2.3).

\subsection{Culture is a sticky, homogenous, and deep factor}

The ethnic group is referred to in one of the widely used definitions of culture in economics (Guiso et al. 2006: 36) as one type of those groups - in addition to religious and social ones that transmit the beliefs and values that constitute culture. ${ }^{2}$ There are at least two reasons why such values and beliefs are deep and slow-moving (Roland 2004): the persistence of ethnicity and religion.

The importance of ethnicity is supported by the literature on how ancestry affects current institutions, values and beliefs, and economic development. Spolaore and Wacziarg (2009) find that the barriers to technology adoption are so deeply rooted that, using countries as observations, it correlates with genetic distance from the technology leader. Genetic distance, however, correlates well (and positively) with measures of linguistic, religious, and cultural distance (Spolaore - Wacziarg 2016), and with 'cultural distance along the individualism-collectivism dimension' (Gorodnichenko - Roland 2017: 408). If cultural differences have such deep-seated roots, it is not countries or any other geographical locations whose cultures are different, but those of the populations that inhabit them, as suggested by Putterman and Weil's (2010) results. The Unites States seems to fit this story well (Easterly - Levine 2016; Putterman - Weil 2010: 1651), yet it is an outlier in the regressions (Caplan - Weinersmith 2019: 123-125).

Some elements of culture might be less deep than others, but it is not completely clear which ones. Those that change faster might be the ones that 'generate larger transaction gains from assimilation' (Giavazzi et al. 2019: 121) or the 'possibly contingent ideas about the appropriate macroeconomic policy framework' (Alesina et al. 2017: 172). Beliefs as regards how the economy works fit the latter description, but probably do not fit the former.

Another reason for the depth and slow-changing nature of culture is that 'many norms are rooted in religions' (Roland 2004: 117). Christianity and Judaism might be exceptional in providing an ethical basis for human freedom (Siedentop 2014; Hill 2019), but Christianity's political-economic history is also different from Islam in a way that creates a fertile soil for political freedom and for thinking about it (Rubin 2017). Anyway, the economic beliefs of individuals are indeed influenced by religion and religiosity (Guiso et al. 2003).

Following the line of research first initiated by Weber (1904-5/2001), several authors (Arruñada - Krapf 2019; Arruñada 2010; Nelson 2012) conclude that the Protestant-Catholic divide is still relevant today and is partially responsible for cultural and institutional differences

\footnotetext{
${ }^{1}$ For a more wide-ranging review of the field of 'culture and institutions' or 'culture and economic development' see, for example, Alesina and Giuliano (2015); for a review on the literature on trust, one of the most widely researched 'soft' concepts, see Győrffy (2017).

${ }^{2}$ In this section, therefore, the word 'culture' is meant in the same way.
} 
within Europe, including the North-South division in the capitalist spirit of the continent (Bruni - Milbank 2019). Protestantism has also been shown to matter for economic freedom worldwide (Hillman - Potrafke 2016).

In addition to ethnicity and religion, culture might be the result of a very long-run coevolution of values and institutions. In one of the seminal papers, Tabellini (2010) presents evidence that cultural differences measured as differences in various values observable in the World Values Survey (trust, respect, obedience, control over life) are able to predict differences in economic development between regions of Western Europe, and these values are predicted by the civic history of the regions. Cultural differences are thus persistent (Guiso et al. 2016: 1434), suggesting that a 'nation's psyche' is linked to 'historical events'.

Some doubts have been raised about the 'deep culture matters' story. Desmet et al. (2017) find that ethno-linguistic diversity does not correlate with cultural diversity. Murphy (2019) concludes, in the context of the debate on the effect of immigration on institutions, that deep, ethnicity-based culture might not be as important for the institutions of countries as it first seems. The roots of the difference concerning the right economic policy, such as 'French' and 'German' thinking about free markets, government or personal responsibility (Brunnermeier et al. 2016; Guiso et al. 2016), are usually not found in the very distant past.

In sum, this literature finds that culture is a deep, mainly unconscious determinant of behaviour that can therefore be one factor among the many that explain institutional and economic development. Its depth is derived from the long history of an ethnic group or from a long-run political history of a certain region.

\subsection{Culture is an elusive and heterogeneous context}

What the approach reviewed above ignores when thinking about values is discussion (McCloskey 2016), even though understanding the relevance of survey questions would necessitate a 'theory of talk' (Tollison 1986: 919). This suggests that the political economy approach that emphasizes discussion (Levy - Peart 2020; Emmett 2020) might add something to the insights about culture reviewed above.

A starting point of such a view could be the Buchananite notion of moral communities (Buchanan 1987; Munger 2020), several of which everyone identifies with. The identification with several communities provides those shared meanings which Storr and John (2020: 20) argue is the proper understanding of culture: 'culture is the lens through which [people] interpret and make sense of their actions, opportunities, and environment'. In this approach, culture can be seen as a constitution (John 2015), or at least like (Stein 2014) a constitution. ${ }^{3}$

There are at least three conclusions from this 'Austrian' understanding of culture that are worth emphasizing here. First, it is far from obvious that one national culture exists (Lavoie Chamlee-Wright 2001: 59-60; Aligica - Matei 2015) and even if there is one, it is much less linked to ethnicity than is suggested by the mainstream view. There are several moral communities within a society, and only one of them is that of people with common ethnic roots. There might be different cleavages (Runst 2015), including inter-generational differences

\footnotetext{
${ }^{3}$ Buchanan (2001: 46:40) himself seems to include culture in the notion of a constitution when defining it 'as being the set of rules, conventions, traditions, within which a society more or less operates and which people empirically sort of accept as guidelines or a framework within which they carry on their ordinary activities, both private and public.'
} 
(Benczes - Ságvári 2018), and 'competing economic spirits' (Storr 2013: 95) within the same society.

Second, what is measured by surveys is not culture but some result of it. Answers to surveys reflect what people think, not how they think. It is, however, the how that culture is (John 2015: 234-235) while it is the what that surveys reflect. Answers to survey questions (values and beliefs) are therefore a result of a process of interpreting the world with the help of culture.

Third, values and beliefs may partially result from the discussion framed by the country's institutions (Mike 2017), which are confined by explicit borders. Political borders will therefore matter for culture, even for people with the same traditions represented by their ethno-linguistic community or their history.

\subsection{East Central Europe as a testing ground}

One region of the world where one can test the conclusions of Sections 2.1 and 2.2 is East Central Europe, that part of Central and Eastern Europe which has been influenced the most by the West (Foldvari 2018). Taking a closer look at this region of small nations and diverse histories might help us see the consequences of cultural heterogeneity without large differences in climate, geography, economic development, or genetics. ${ }^{4}$

Several authors, implicitly or explicitly, have come up with the idea that what is responsible for the different institutional and development paths in the region are values and beliefs. Although Beck and Laeven (2006) use the time spent in socialism by the country as a proxy for the entrenchment of the old elite, it can quite plausibly stand for the influence of communist rule on culture (Runst 2015: 321), which does not seem to go away very easily (Alesina - FuchsSchündeln 2007; Runst 2013). Attitudes toward the market economy then predict the institutional paths (Runst 2014).

Religion appears here, too, as an explanation for different beliefs (Runst 2014). The border between 'Latin' and Eastern Christianity cuts through the region - a fact with economic significance (Hodgson 2006; Zweynert - Goldschmidt 2006). Religiosity and religious affiliation, too, shape beliefs in the post-communist region (Minarik 2014; 2019).

The countries of the region were cut through by different empires, whose significance for current economic, institutional, and cultural developments has also been shown (Becker et al. 2016; Dimitrova-Grajzl 2007; Grosjean 2011). These authors conjecture that the effects of these old political communities have a lasting effect because they shaped the beliefs of the people living in them, and these beliefs, through a mechanism which is not very clear, have managed to live on up to the present. For the countries that will be examined in the rest of this paper, it is the Habsburg Empire (Austria - Hungary) and the Kingdom of Hungary that are relevant.

To study the effect of living in the same country on beliefs, I will focus on Hungary, Romania, Slovakia, and Serbia. Borders changed here quite abruptly and to such a great extent as

${ }^{4}$ Even Hungarians, speaking a Non-Indo-European language, are genetically hardly different from the people living in the neighbouring countries (Spolaore - Wacziarg 2016: 196). 
a result of the Paris Peace Settlements closing the First World War that the 'Treaty of Trianon' is considered one of the major events of Hungarian history. Historical, ethnic and religious borders were then crossing political borders, as they are today. Substantial numbers of ethnically and linguistically Hungarian people live in Slovakia, Ukraine, Romania, Croatia, Serbia, and even Austria. $^{5}$

By making use of ethnic and cultural unity across political borders my approach is similar to that of Posner (2004) who is concerned with the Zambia - Malawi political and the Chuwa Tumbuka ethnic border. ${ }^{6}$ The weakness of my East Central European focus might be that ethnic diversity in the small region I look at is much less than in Africa. Its strength is the possibility to include more than two countries in the analysis with people with the same ethnic and cultural identity. As demonstrated by Veres's (2015) analysis of the 'Karpat Panel' survey of Hungarians in 2007, members of the Hungarian minorities in these countries identify with the 'pan-Hungarian nation' (Veres 2015: 97) but also, to a somewhat lesser extent, with their home country, too, producing an identity of 'regional "Hungarianness"', which is 'primarily ethnoculturally Hungarian, with certain elements of Romanian/Slovakian etc. civic identity' (Veres 2015: 104).

\section{EMPIRICAL MODEL AND DATA}

The above implies that a 'country effect' could mean two things in the context of analysing values and beliefs. First, it means the extent to which living in a particular country will shape individual values and beliefs. Such an effect can result from the deeper culture shaped by the long-run history of the country or the ethnolinguistic group in question. Second, it could mean the extent to which the values can be shaped by living in the same country, independently of which country it may be (same-country effect). This effect is hypothesized to result from the ongoing discussion within the confines of the polity. This country effect is linked to the political community while the former effect can also be linked to the ethno-linguistic group or the historical borders.

My main concern is the same-country effect. The regression equation I will run to estimate it has the form

$$
\begin{aligned}
d_{i j}^{A} & =\alpha+\mathbf{x}_{i j} \beta_{1}^{\prime}+\sum_{r_{i}} \sum_{r_{j}} \beta_{2}^{r_{i} r_{j}} \mathrm{R}_{r_{i} r_{j}}+\sum_{\mathrm{k}} \beta_{2}^{k} \mathrm{E}_{k, i}+\sum_{k} \beta_{3}^{k} \mathrm{E}_{k, j}+\beta_{4} \mathrm{SE}_{i j}+\sum_{m=1}^{k-1} \gamma_{1, m} \mathrm{C}_{m, i}+ \\
& +\sum_{m=1}^{k-1} \gamma_{2, m} \mathrm{C}_{m, j}+\gamma_{3} \mathrm{SC}_{i j}+\delta_{1} w_{4 i}+\delta_{2} w_{4 j}+\varepsilon_{i j}
\end{aligned}
$$

where $d_{i j}^{A}$ is the Euclidian difference between certain beliefs of individual $i$ and $j$ for belief area $A$ :

\footnotetext{
5‘The implication of these awards [in the Treaty of Trianon] included: the reduction of Hungary's area by the two-thirds, from 282,000 to 93,000 sq. km.; the reduction of Hungary's population by over half, from 18.2 to 7.9 million; [...] and [...] the transfer over three million ethnic Magyars to Czechoslovak, Romanian, Yugoslav or Austrian rule' (Cartledge 2011: 326-327).
}

${ }^{6}$ I thank an anonymous referee for drawing my attention to Posner's (2004) paper. 


$$
d_{i j}^{A}=\sqrt{\sum_{l \in A}\left(y_{l i}-y_{l j}\right)^{2}},
$$

with $l$ being the number of questions within area $A$, and $y_{l i}$ and $y_{l j}$ the answer individual $i$ and $j$ gave to question $l$, transformed to between 0 and 1 if necessary. Following Beugelsdijk et al. (2019), I identify five areas of values (A): trust, work, gender, market, and democracy. This would mean 26 questions overall, but waves 3 and 4 of the World Values Survey (WVS 2015) which I use in my baseline regressions (Tables 1 and 2, Panel A) do not include all the variables employed by Beugelsdijk et al. (2019). In the baseline results I am able to use 16 questions (variables from this wave): one for trust, five for work, three for gender, two for markets, and five for democracy. ${ }^{7}$ In the robustness checks regressions (Table 2, Panel B and Table 3) I use all the 26 variables: three variables for trust, eleven for work, four for gender, three for markets, and five for democracy. These differences are calculated by taking all possible combinations of individuals and considering that $d_{i j}^{A}=d_{j i}^{A}$, so a pair of the same two individuals should not be included twice. Also, no individual is allowed to create a pair with herself $(i \neq j)$. There are five different dependent variables, therefore: one for each of the five areas.

The vector $\mathbf{x}_{i j}$ consists of the difference in different individual variables between individuals $i$ and $j$, the choice of which is based on previous studies on the determinants of beliefs (Koster 2010; Migheli 2010; 2016) and includes sex (variable X001 in the WVS), the importance of God (F063), birthyear (X002), education (X025), size of town (X049), being religious, and being an atheist (both derived from variable F034). The self-reported income group is not included because there is no observation on it in the Hungarian sample of wave 3.

Following the literature reviewed in Section 2, data on religious denomination (variable F025) are also included as independent variables. These independent variables account for all the 15 possible pairs ${ }^{8}$ of denominations that can be chosen from among the following five: Catholic, ${ }^{9}$ Protestant, ${ }^{10}$ Eastern Christian, ${ }^{11}$ other religion, ${ }^{12}$ and non-religious. ${ }^{13}$ Accordingly, $R_{r_{i} r_{j}}{ }^{\prime} \mathrm{s}$ are the dummies accounting for pairs of religious denominations. That is, $R_{r_{i} r_{j}}=1$ if individual $i$ is reported to belong to religious denomination $r_{i}$ while individual $j$ is reported to belong to religious denomination $r_{j}$; and $R_{r_{i} r_{j}}=0$ otherwise. The lower indices $r_{i}$ and $r_{j}$ denote two of the five religious denominations, with the exception of the case in which both would mean 'nonreligious', which is the reference dummy.

\footnotetext{
${ }^{7}$ The list of questions used in the baseline regressions as well as in the robustness tests are available in the Appendix, Table 4.

${ }^{8}$ Minus one for the reference dummy.

${ }^{9}$ 'Greek Catholic', 'Roman Catholic'. All categories of religious affiliation mentioned in footnotes 9-13 are presented as they can be found in WVS (2015) or EVS (2011).

${ }^{10 ‘}$ Baptist', 'Christian Reform', 'Evangelical, Free church/Non-denominational church', 'Hussite', 'Jehovah's Witnesses', 'Pentecostal', 'Protestant', 'Seven Day Adventist', 'Unitarian'.

${ }^{11}$ 'Orthodox'.

${ }^{12 ‘}$ Buddhist', 'Hindu', 'Jew', 'Muslim', 'Other'.

${ }^{13 ،}$ No religious denomination'.
} 
Table 1. The effects of country, same country, and same ethnicity on value differences

\begin{tabular}{|c|c|c|c|c|c|}
\hline & \multicolumn{5}{|c|}{ Dependent variable: distance between individuals $i$ and $j$ in values } \\
\hline & Trust & Work & Gender & Market & Democracy \\
\hline Slovakia_i & $-0.023^{* * *}(0.002)$ & $0.047^{* * *}(0.002)$ & $-0.013(0.002)$ & $0.003^{* * *}(0.001)$ & $-0.120^{* * *}(0.001)$ \\
\hline Romania_i & $0.028^{* * *}(0.002)$ & $0.017^{* * *}(0.002)$ & $0.015^{* * *}(0.002)$ & $0.133^{* * *}(0.001)$ & $0.061^{* * *}(0.002)$ \\
\hline Serbia_i & $0.036^{* * *}(0.003)$ & $0.115^{* * *}(0.004)$ & $0.133^{* * *}(0.003)$ & $0.095^{* * *}(0.002)$ & $-0.083^{* * *}(0.002)$ \\
\hline Slovakia_j & $-0.026^{* * *}(0.003)$ & $0.049^{* * *}(0.003)$ & $0.001(0.003)$ & $-0.055^{* * *}(0.002)$ & $-0.100^{* * *}(0.002)$ \\
\hline Romania_j & $0.013^{* * *}(0.004)$ & $0.026^{* * *}(0.005)$ & $0.091^{* * *}(0.004)$ & $0.075^{* * *}(0.003)$ & $0.055^{* * *}(0.004)$ \\
\hline Serbia_j & $0.056^{* * *}(0.003)$ & $0.000(0.003)$ & $0.158^{* * *}(0.003)$ & $-0.045^{* * *}(0.002)$ & $-0.102^{* * *}(0.002)$ \\
\hline same country & $0.002(0.002)$ & $-0.078^{* * *}(0.002)$ & $-0.043^{* * *}(0.001)$ & $-0.063^{* * *}(0.001)$ & $-0.021^{* * *}(0.001)$ \\
\hline same ethnicity & $-0.005^{* * *}(0.001)$ & $-0.016^{* *}(0.001)$ & $0.005^{* * *}(0.001)$ & $0.011^{* * *}(0.001)$ & $-0.003(0.001)$ \\
\hline obs. & $4,878,126$ & $4,878,126$ & $4,878,126$ & $4,878,126$ & $4,878,126$ \\
\hline$R^{2}$ & 0.013 & 0.017 & 0.014 & 0.018 & 0.048 \\
\hline
\end{tabular}

Independent variables that are not shown but included in the regression: the absolute difference of the variables sex, the importance of God, birthyear, education, size of town, being religious, and being an atheist; all possible pairs of religions - Catholic, Protestant, Eastern Christian, other religion, and nonreligious; all possible ethnicities or languages (if ethnicity is not applicable) for individuals $i$ and $j$ (omitted dummy is Hungarian). ${ }^{* * *}: p<0.01,{ }^{* *}: p<0.05$. Standard errors (in parentheses) are robust. 
Table 2. Same-country effects within Hungarian respondents and with $\mathrm{KOH}$ regions controlled

\begin{tabular}{|c|c|c|c|c|c|}
\hline & \multicolumn{5}{|c|}{ Dependent variable: distance between individuals $i$ and $j$ in values } \\
\hline & Trust & Work & Gender & Market & Democracy \\
\hline \multicolumn{6}{|c|}{ Section A: Hungarian respondents only } \\
\hline same country & $-0.008(0.016)$ & $-0.080^{* * *}(0.021)$ & $-0.133^{* * *}(0.014)$ & $-0.088^{* * *}(0.010)$ & $-0.027^{* *}(0.012)$ \\
\hline obs. & 90,100 & 90,100 & 90,100 & 90,100 & 90,100 \\
\hline$R^{2}$ & 0.018 & 0.025 & 0.080 & 0.053 & 0.041 \\
\hline \multicolumn{6}{|c|}{ Section B: Accounting for $\mathrm{KOH}$ regions } \\
\hline same country & $-0.003^{* * *}(0.001)$ & $-0.075^{* * *}(0.002)$ & $-0.008^{* * *}(0.001)$ & $-0.034^{* * *}(0.001)$ & $-0.042^{* * *}(0.001)$ \\
\hline KOH & $0.004^{* * *}(0.001)$ & $0.007^{* * *}(0.001)$ & $0.023^{* * *}(0.001)$ & $0.045^{* * *}(0.001)$ & $0.026^{* * *}(0.001)$ \\
\hline obs. & $3,614,016$ & $3,255,076$ & $3,614,016$ & $3,614,016$ & $3,614,016$ \\
\hline$R^{2}$ & 0.011 & 0.013 & 0.035 & 0.034 & 0.018 \\
\hline
\end{tabular}

Independent variables that are not shown but included in the regression: the absolute difference of the variables sex, the importance of God, birthyear, education, size of town, being religious, and being an atheist; all possible pairs of religions - Catholic, Protestant, Eastern Christian, other religion, and nonreligious. ${ }^{* * *}: p<0.01,{ }^{* *}: p<0.05$. Standard errors (in parentheses) are robust. 
Table 3. Same-country effects within KOH regions and accounting for NUTS regions

\begin{tabular}{|c|c|c|c|c|c|}
\hline & \multicolumn{5}{|c|}{ Dependent variable: distance between individuals $i$ and $j$ in values } \\
\hline & Trust & Work & Gender & Market & Democracy \\
\hline \multicolumn{6}{|c|}{ Section A: Accounting for NUTS 2 regions } \\
\hline same country & $-0.005^{* * *}(0.001)$ & $-0.080^{* * *}(0.002)$ & $-0.008^{* * *}(0.0061)$ & $-0.033^{* * *}(0.001)$ & $-0.042 * * *(0.001)$ \\
\hline obs. & $3,614,016$ & $3,255,076$ & $3,614,016$ & $3,614,016$ & $3,614,016$ \\
\hline$R^{2}$ & 0.032 & 0.015 & 0.043 & 0.049 & 0.031 \\
\hline \multicolumn{6}{|c|}{ Section B: Accounting for NUTS 2 regions within $\mathrm{KOH}$ area } \\
\hline same country & $-0.004(0.002)$ & $-0.192^{* * *}(0.005)$ & $0.001(0.002)$ & $-0.068^{* * *}(0.002)$ & $-0.080^{* * *}(0.002)$ \\
\hline obs. & $1,420,455$ & $1,293,636$ & $1,420,455$ & $1,420,455$ & $1,420,455$ \\
\hline$R^{2}$ & 0.028 & 0.0163 & 0.058 & 0.069 & 0.037 \\
\hline
\end{tabular}

Independent variables that are not shown but included in the regression: the absolute difference of the variables sex, the importance of God, birthyear, education, size of town, being religious, and being an atheist; all possible pairs of religions - Catholic, Protestant, Eastern Christian, other religion, and nonreligious. ${ }^{* * *}: p<0.01,{ }^{* *}: p<0.05$. Standard errors (in parentheses) are robust. 
Variables $\mathrm{E}_{k, i}$ and $\mathrm{E}_{k, j}$ are dummies for the ethno-linguistic group of individuals $i$ and $j$. Ethno-linguistic group is defined by ethnicity as reported in the WVS-EVS database (variable $\mathrm{X} 051$ ) or, if ethnicity is not reported, by language used at home (variable G016). Following this rule the number of dummy variables accounting for different ethno-linguistic groups turns out to be fourteen, ${ }^{14}$ with the Hungarian ethnicity dummy being the one omitted. $\mathrm{SE}_{i j}$ is also a dummy variable to account for a case in which individuals $i$ and $j$ belong to the same ethnolinguistic group.

$\mathrm{C}_{m, i} \mathrm{C}_{m, j}$ are country dummies that account for the country (m) of individual $i$ and that of individual $j$, with $m=$ Hungary as the omitted dummy. $\mathrm{SC}_{i j}$ is a dummy that shows whether $\left(\mathrm{SC}_{i j}=1\right)$ or not $\left(\mathrm{SC}_{i j}=0\right)$ both individuals live in the same country. As a testing ground for such a same-country effect I have three reasons to concentrate on Hungary, Romania, Slovakia, and Serbia, in addition to the fact that this part of Central Europe may be interesting in itself, as was explained in Section 2.3. First, the fact that the database includes observations of the respondent's ethnicity or language makes it possible to check the effect of current political borders, controlling for ethnic or linguistic identity. While the authors of the literature discussed in Section 2 are usually interested in the effect of ethnic differences within a country (Desmet et al. 2017), in this case it is possible to examine the effect of country differences within an ethnic group.

Second, to examine the same-country effect, we need pairs of individuals as dependent variables, which leads to a large number of observations even with small country samples. With many countries the number of observations might grow too large to be dealt with by traditional econometric tools. However, to separate the same-country effect we need at least three countries. With only two countries $(k=2)$, the $\mathrm{SC}_{i j}$ variable will be perfectly collinear with the two country dummies. $^{15}$

Third, focussing on Hungary and its three neighbouring countries makes the other determinants of beliefs quite similar because the ethno-linguistic groups are geographically and genetically very close to each other. However, it is possible to run the regression with at least three countries within the same ethno-linguistic group (Hungarian) or within the same historical region (Kingdom of Hungary), which makes a good robustness checks of the original results.

Finally, $\mathrm{w}_{4 i}$ and $\mathrm{w}_{4 j}$ are wave dummies to account for the fact that in the baseline regressions that follow not all the observations are from the same wave of the WVS. The majority of the observations are from wave 3 but quite a few are from wave 4 .

As my main concern is the same-country effect, the coefficient of a dummy, I will not suppose nonlinear effects or introduce cross-variables of the control variables. Also, the theory I am testing does not clearly suggest any nonlinearities. ${ }^{16}$ The data ${ }^{17}$ for the baseline regressions

\footnotetext{
${ }^{14}$ Albanian, Bosnian, Czech, English, German, Montenegrin, Romanian, Romany, Serbian, Slovak, Ukrainian other, more than one, white.

${ }^{15} \mathrm{SC}_{i j}=1+\mathrm{C}_{1 i}-\mathrm{C}_{1 j}$, considering the fact that the case $\mathrm{C}_{1 i}=0$ and $\mathrm{C}_{1 j}=1$ can be excluded since every pair of people appears only once.

${ }^{16}$ Testing for such a hypothesis might be the subject of some further analysis that is beyond the scope of this paper. I thank an anonymous referee for this suggestion.

${ }^{17}$ Every detailed statistic not presented here, including the descriptive statistics of the variables and the detailed results of the regressions, is available from the author.
} 
come from waves 3 (1994-1998) and 4 (1999-2004) of the World Values Survey, as can be found in the World Values Survey-European Values Study combined database (WVS 2015; EVS 2011), an often used source of data on values and beliefs. The reason for choosing this wave is that all the three countries that have the most substantial Hungarian minorities - Romania, Serbia, and Slovakia - are included. ${ }^{18}$ No other waves of the WVS include all the four countries except for the most recent (preliminary) one (2017-2020) which does not provide information on ethnicity or language. In the robustness test regressions I use data from wave 4 of the EVS which covers the year 2008 and lacks data on ethnicity or language but includes data on regions of the respondent. This suggests we should be cautious in interpreting the results because there has been some institutional divergence between the countries since the years these surveys were carried out.

I will use simple ordinary least squares (OLS) to estimate Eq. (1). One reason for this is that I follow those authors (Migheli 2016; Guiso et al. 2003; Pitlik - Kouba 2015) who ask a question similar to mine and analyse individual-level data. Second, my dependent variables are more or less continuous by construction (Eq. (2)). The only exception is difference in trust for the baseline regression, in which case the dependent variable is calculated from one single question with binary answers. For the sake of comparability with the other results I use an OLS estimation here, too, meaning I use a linear probability model for the trust difference in Table 1 . The ease of the interpretation of the coefficients is my third reason to use simple OLS estimations. Coefficients can be seen as a change in the difference as a result of a common country, common ethnicity etc., which I will put in perspective by comparing it to the effect of a change in (selfreported) education level which runs between 0 (inadequately completed elementary education) and 7 (university with degree). Education, after all, is explicitly aimed at affecting what and how people think.

\section{REGRESSION RESULTS AND ROBUSTNESS CHECKS}

Table 1 shows the results for Eq. (1) run with data from waves 3 and 4 of the WVS. ${ }^{19}$ For the sake of brevity only the coefficients of the country, same-country and the same-ethnicity dummies are shown. Each of the five columns is concerned with one of the groups of values for which individual distances are calculated. Since the differences between all the possible pairs of people are calculated as independent variables, the number of observations is quite large, and the $R$ squares are quite small.

The fact that the $R$ squares are very small as compared to those in cross-country regressions, for example, might not be that surprising if we consider the following. The dependent variables are observations on beliefs and values of particular individuals, which are not aggregated in any way. Therefore we cannot expect that much of the variance can be explained by what can be recorded in a survey. And, after all, this is good news if we think that a person's opinion should

\footnotetext{
${ }^{18}$ The samples from Croatia, and Ukraine do not include any Hungarians, while Austria is not included in any WVS wave (only in the EVS, which does not provide information on ethnicity).

${ }^{19}$ The summary statistics of the variables in Table 1 are presented in the Appendix (Table 5). Further summary statistics are not presented due to reasons of saving space, but available upon request, as are the group wise F-statistics that justify the inclusion of the control variables.
} 
be independent of his or her observable characteristics because it should be the result of 'disinterested contemplation'. Indeed, in those studies in which individual opinions are regressed

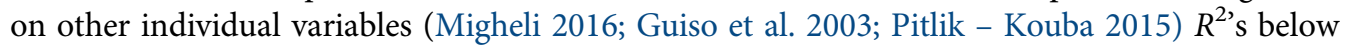
0.1 are quite common. ${ }^{20}$

The variables Hungary and Hungarian being the omitted country and ethnic dummies, country effects should be understood as compared to Hungarians in Hungary. For example, all their other controlled characteristics being the same, two Hungarians in Slovakia are estimated to have a $0.055-0.003=0.052$ smaller difference between them in market-related values than do two Hungarians in Hungary, while two Hungarians in Romania are predicted to be $0.133+$ $0.075=0.208$ more distant.

The coefficients of the individual characteristics and religion pairs, which are not shown in Table 1, are also statistically significant. Taking market-related values again as an example, the difference between a person with a university degree and one with an unfinished elementary school education is estimated to be 0.028 units larger than between two people with the same level of education. Two Protestants are predicted to have 0.029 less distance between them than are two non-religious people.

Three interesting conclusions can be drawn form Table 1. First, the same-country effect is significant statistically (at the usually accepted levels of significance) in four of the five cases even after controlling for the country effects of both individuals. Trust seems to be an area where living in the same country does not cause people's views to be more similar. In addition, the same-country effect is negative every time when it is significant, showing that - independently of their country and ethno-linguistic groups - those who live in the same country have more similar views than those who do not, as predicted by the approach that sees the discussion within the political community as shaping values and beliefs.

In the case of market beliefs, the same-country effect is estimated to be more than twice that of the difference caused by the largest difference in education between individuals $i$ and $j$ (inadequately completed elementary vs university with a degree). ${ }^{21}$ Second, the same-country effect is more important than the same-ethnicity effect. The latter is significant four times, negative only twice, and its size is also much smaller.

The results in Table 1 support the hypothesis that the political community shapes values and beliefs. To check for the robustness of these results a couple of other regressions will be presented, the main concern of which is to account for culture in a different way than by including ethnicity in the regression as an independent variable.

The first of such robustness checks is the running of the regressions in Table 1 with the same database restricted to Hungarians. As I explained in Section 2.3, this robustness check is the main reason to choose Hungary and Hungarians as the main focus of this paper. Language, which I use as a proxy for ethnicity when ethnicity itself is not available, seems a very good approximation of ethnicity for Hungarians. The use of the Hungarian language, being somewhat

\footnotetext{
${ }^{20}$ Guiso et al. (2003: 243-247) find $R^{2}$ 's between 0.042 and 0.279 , Migheli (2016: 684-688) between 0.033 and 0.141 , and Pitlik and Kouba (2015: 364-374) between 0.025 and 0.145. But these authors study individual beliefs, not the differ-

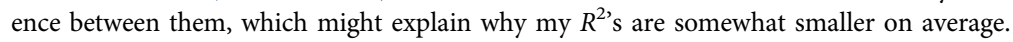

${ }^{21}$ The coefficient of the education difference (not shown in the table), is 0.004 with a $p<0.0005$. As mentioned, the education variable runs on a scale between 0 (inadequately completed elementary education) and 7 (university with degree).
} 
special in Europe is almost exclusively restricted to those who are ethnically or culturally Hungarian. ${ }^{22}$ Such a restriction of the sample makes it possible to estimate the country effect within an ethno-linguistic group whose members see themselves as belonging to the same cultural community. But since some of them live in one of the four countries in the sample, it is also possible to estimate the same-country effect within them and still account for the country effects as in Table 1.

The estimations with such a restricted sample, which includes many fewer observations, are shown in Section A of Table 2. The effects of living in the same country are still significant (at the usually expected level) as a determinant of the individual distance for beliefs about gender and for market beliefs. The size of the latter is estimated to be more than five times as high as that of the highest possible difference in education. ${ }^{23}$

Yet another, and much more fundamental, concern with the results in Table 1 is that being a member of an ethno-linguistic community is not the right proxy for a common culture. An alternative one may be, as suggested by the literature review in Section 2, a historical-geographical definition of culture. For the countries under consideration, it is the Habsburg Empire that has been shown to be relevant (Becker et al. 2016; BenYishay Grosjean 2014). I will, however, not use the Empire as a proxy but the Kingdom of Hungary (KOH). Although the authors I cited do not make a difference between the two, ${ }^{24}$ I can see some reasons to do so. First, because for four hundred years before 1918, the Kingdom of Hungary was part of the Habsburg Empire, although as a political community it had existed well before the Habsburgs, roughly since $1000 \mathrm{AD}$. If the length of the period is the key, the Kingdom of Hungary should matter more than the Habsburg Empire. Confined to just four countries, two of which (Hungary and Slovakia) were 100 percent a $\mathrm{KOH}$ region, this dilemma concerns only Romania and Serbia. In Serbia the $\mathrm{KOH}$ and Habsburg borders were the same in the year (1900) for which the results of Becker et al. (2016) are robust. In Romania the former Empire includes one county (Suceava) more than does the former $\mathrm{KOH}$.

In the analysis, the results of which are shown in section B of Table 2, common culture is measured by whether individuals $i$ and $j$ both live in a region which used to be part of the Hungarian Kingdom before 1918. For this analysis I am not able to use the same data as for Table 1 or Section A of Table 2 because there are no data on within-country regions in the WVS wave I used there. I will use instead data in the EVS wave 4 (covering the year 2008) within the WVS-EVS database (EVS 2011; WVS 2015) which includes NUTS2 level data that allows us to

\footnotetext{
${ }^{22}$ A proverb, very often used in Hungary, according to which 'nations exist in their own language' (Péter 2012: 184) is obviously false in general but seems to be right for Hungary in particular. According to the survey results presented by Veres (2015: 95), an overwhelming majority of Hungarian minorities define their national identity by 'my mother tongue, my culture'.

${ }^{23}$ The coefficient of the education difference is 0.002 with a $p<0.0005$.

${ }^{24}$ According to Becker et al. (2016: 46, footnote 15), 'of the five countries in our main empirical analysis below, the Hungarian part was active in one country (Romania) only, and we show that results are not sensitive to dropping Romania from the analysis altogether'. BenYishay and Grosjean (2014: 898) also refer to the 'Habsburg Empire' as 'what was the Kingdom of Hungary and the Austrian Empire and became the Austria-Hungarian [sic] Empire after the 1867 Ausgleich.' Roland (2020: 501-502), however, arguing for the importance of long-run history, associates Hungary and Slovakia with the Arpad Dynasty, the first royal dynasty of the Kingdom of Hungary.
} 
separate former $\mathrm{KOH}$ regions in Romania and Serbia, ${ }^{25}$ while the full area of Hungary and Slovakia are considered $\mathrm{KOH}$ regions. As this is the original database for which Beugelsdijk et al. (2019) identified those five groups of values I calculate the distances from in order to get the dependent variables in the regressions, the list of variables is now complete. As a result, the dependent variables in Section B of Table 2 and in Table 3 are different from those in Table 1 and Section A of Table 2 inasmuch as in the former cases, distances are calculated from more variables. $^{26}$

The results in section $\mathrm{B}$ of Table 2 are similar to those in Table 1, as the same-country dummy is significant for several value distances, all of them in this case. With differences in work-, market-, and democracy-related values as dependent variables the same-country effect is still statistically and economically significant: the effect of being in the same country for marketrelated values is 1.3 times the effect of the largest difference in education. ${ }^{27}$ The signs of these effects are in line, too, with the discussion hypothesis. Surprisingly, the $\mathrm{KOH}$ dummy itself is significant with a positive sign - the opposite of what would have been expected when seeing it as a proxy for long-run history that makes people have similar values.

Sections A and B of Table 3 present two other possibilities to restrict the sample of Table 2 Panel $\mathrm{B}$ and, therefore, check the robustness of the baseline results. In section $\mathrm{A}$ regional dummies accounting for all the 22 NUTS 2 regions within the four countries are included. ${ }^{28}$ The coefficients of the same-country effect remain significant, even their sizes are quite similar. In section $\mathrm{B}$, the regressions are run with the same regional dummies on a sample restricted only to the $\mathrm{KOH}$ region. Although this restriction reduces the sample substantially, the same-country effect is significant in three cases again. Its size has increased, however, which could be surprising if we did not know that the $\mathrm{KOH}$ dummy was estimated to have a positive sign above in Table 2.

\section{CONCLUSIONS}

To answer the question I asked in the title of this paper I have focused on Hungary and its neighbouring countries and tested the hypothesis that claims that the fact that two people share the same political (discussion) community is a determinant of the differences between their beliefs and values even after controlling for their ethnicity, country, and other individual characteristics. The hypothesis is based on the tradition in political economy that looks at the polity as an ongoing discussion to discover one's own preferences. It turns out that the samecountry effects are all significant but they are not the same for all groups of values. Differences in trust and gender-related values are less robustly affected than are work-, market-, and democracy-related ones.

\footnotetext{
${ }^{25}$ Romania: Macroregiunea unu - Nord-Vest, Macroregiunea unu - Centru, Macroregiunea patru - Vest; Serbia: Vojvodina.

${ }^{26}$ See the Appendix for a list of variables included.

${ }^{27}$ The coefficient of the education difference is 0.004 with a $p<0.0005$.

${ }^{28}$ Their coefficients, as well as those of the country dummies, are not shown to save space, but all the results are available from the author.
} 
The answer to the question is then that it is political borders that affect values and beliefs more. Given that the results are confined to a small region of the world, we should be cautious about drawing general conclusions, though Posner (2004) comes to similar ones by examining a very different region. With these caveats in mind, I will risk drawing three more general conclusions. First, the results cast some doubt on the idea that values and beliefs are rooted deeply and are, as a result, very slow to change. Second, the results might give us an additional reason why we should see institutional change as a coevolution of culture and institutions, and might point to a particular channel of this coevolution, which is the discussion framed by formal institutions. Third, this idea has some policy relevance as well. Different policies, the results suggest, might not only lead to different rules of the game but, by shaping the discussion, they can lead the players to interpret those rules of the game differently than before. It might not be possible, then, for the players to know in advance whether or not some institutions and policies are 'in line' with their culture.

\section{ACKNOWLEDGEMENT}

This paper was supported by the Hungarian National Research, Development, and Innovation Office (project no.: K-120686). With the usual caveats, I am grateful for two anonymous referees for their helpful comments.

\section{REFERENCES}

Alesina, A. - Fuchs-Schündeln, N. (2007): Good-Bye Lenin (or Not?): The Effect of Communism on People's Preferences. American Economic Review 97(4): 1507-1528.

Alesina, A. - Giuliano, P. (2015): Culture and Institutions. Journal of Economic Literature 53(4): 898-944.

Alesina, A. - Tabellini, G. - Trebbi, F. (2017): Is Europe an Optimal Political Area? Brookings Papers on Economic Activity 48(1): 169-213.

Aligica, P. D. - Matei, A. (2015): National cultures, economic action and the homogeneity problem: insights from the case of Romania. In: Grube, L. E. - Storr, V. H. (eds): Culture and Economic Action. Cheltenham, UK: Edward Elgar, pp. 295-317.

Arruñada, B. (2010): Protestants and Catholics: Similar Work Ethic, Different Social Ethic. The Economic Journal 120(547): 890-918.

Arruñada, B. - Krapf, M. (2019): Religion and the European Union. In: Carvalho, J.-P. - Iyer, S. - Rubin, J. (eds): Advances in the Economics of Religion. Cham, Switzerland: Palgrave MacMillan, pp. 295-308.

Beck, T. - Laeven, L. (2006): Institution Building and Growth in Transition Economies. Journal of Economic Growth 11(2): 157-186.

Becker, S. O. - Boeckh, K. - Hainz, C. - Woessmann, L. (2016): The Empire is Dead, Long Live the Empire! Long-Run Persistence of Trust and Corruption in the Bureaucracy. The Economic Journal 126(590): 40- 74 .

Beugelsdijk, S. - Klasing, M. J. - Milionis, P. (2019): Value Diversity and Regional Economic Development. Scandinavian Journal of Economics 121(1), 153-181. 
Benczes, R. - Ságvári, B. (2018): Life is a Battlefield: Conceptualizations of Life among Hungarian Adults. Society and Economy 40(4): 571-586.

BenYishay, A. - Grosjean, P. (2014): Initial Endowments and Economic Reform in 27 Post-Socialist Countries. Journal of Comparative Economics 42(4): 892-906.

Bruni, L. - Milbank, J. (2019): Martin Luther and the different spirits of capitalism in Europe. International Review of Economics 66(3): 221-231.

Brunnermeier, M. K. - James, H. - Landau, J.-P. (2016): The Euro and the Battle of Ideas. Princeton: Princeton University Press.

Buchanan, J. M. (1987): Moral Community, Moral Order, or Moral Anarchy. In: Buchanan, J. M. (eds): Economics: Between Predictive Science and Moral Philosophy. College Station, Texas: Texas A \& M University Press, pp. 289-302.

Buchanan, J. M. (2001): A Conversation with James M. Buchanan Parts I and II. Intellectual Portrait Series Collection, Library of Economics and Liberty. https://www.econlib.org/archives/2013/10/james_ buchanan_conversation.html, accessed: 01/04/2021.

Caplan, B. - Weinersmith, Z. (2019): Open Borders: The Science and Ethics of Immigration. New York: First Second.

Cartledge, B. (2011): The Will To Survive: A History of Hungary. London, UK: Hurst and Company.

Desmet, K. - Ortuño-Ortín, I. - Wacziarg, R. (2017): Culture, Ethnicity, and Diversity. American Economic Review 107(9): 2479-2513.

Dimitrova-Grajzl, V. (2007): The Great Divide Revisited: Ottoman and Habsburg Legacies on Transition. Kyklos 60(4): 539-558.

Easterly, W. - Levine, R. (2016): The European Origins of Economic Development. Journal of Economic Growth 21(3): 225-257.

Emmett, R. B. (2020): James M. Buchanan and Frank H. Knight on democracy as "government by discussion". Public Choice 183(3-4): 303-314.

EVS (2011): European Values Study Longitudinal Data File 1981-2008 (EVS1981-2008). GESIS Data Archive. https://doi.org/10.4232/1.11005.

Foldvari, P. (2018): Central and Eastern Europe. In: Blum, M. - Colvin, C. L. (eds): An Economist's Guide to Economic History. London: Palgrave Macmillan, pp. 277-284.

Giavazzi, F. - Petkov, I. - Schiantarelli, F. (2019): Culture: Persistence and Evolution. Journal of Economic Growth 24(2): 117-154.

Gorodnichenko, Y. - Roland, G. (2017): Culture, Institutions, and the Wealth of Nations. Review of Economics and Statistics 99(3): 402-416.

Grosjean, P. (2011): The Weight of History on European Cultural Integration: A Gravity Approach. American Economic Review 101(3): 504-508.

Guiso, L. - Herrera, H. - Morelli, M. (2016): Cultural Differences and Institutional Integration. Journal of International Economics 99(1): S97- S113.

Guiso, L. - Sapienza, P. - Zingales, L. (2003): People's Opium? Religion and Economic Attitudes. Journal of Monetary Economics 50(1): 225-282.

Guiso, L. - Sapienza, P. - Zingales, L. (2006): Does Culture Affect Economic Outcomes? Journal of Economic Perspectives 20(2): 23-48.

Guiso, L. - Sapienza, P. - Zingales, L. (2016): Long-Term Persistence. Journal of the European Economic Association 14(6): 1401-1436.

Györffy, D. (2017): Soft Concepts in Economics: The Challenges of Researching Trust. Society and Economy 39(3): 301-320. 
Hill, P. J. (2019): The Religious Origins of the Rule of Law. Journal of Institutional Economics 16(3): 305318.

Hillman, A. L. - Potrafke, N. (2016): Economic Freedom and Religion. Public Finance Review 46(2): 249275.

Hodgson, G. M. (2006): Institutions, Recessions and Recovery in the Transitional Economies. Journal of Economic Issues 40(4): 875-894.

John, A. (2015): Culture as a Constitution. In: Grube, L. E. - Storr, V. H. (eds): Culture and Economic Action. Cheltenham, UK: Edward Elgar, pp. 225-242.

Koster, F. (2010): Welfare State Attitudes and Economic Integration in the European Union, 1992-2002: A Multilevel Investigation across 24 Countries. Policy \& Politics 38(2): 179-195.

Lavoie, D. - Chamlee-Wright, E. (2001): Culture and Enterprise: The Development, Representation and Morality of Business. New York: Routledge.

Levy, D. M. - Peart, S. J. (2020): Towards an Economics of Natural Equals: A Documentary History of the Early Virginia School. Cambridge, UK: Cambridge University Press.

McCloskey, D. N. (2016): Max U versus Humanomics: A Critique of Neo-institutionalism. Journal of Institutional Economics 12(1): 1-27.

Migheli, M. (2010): Supporting the Free and Competitive Market in China and India: Differences and Evolution over Time. Economic Systems 34(1): 73-90.

Migheli, M. (2016): Behind the Wall: What Remains of the "Communist Legacy" in Contemporary Europe. Social Indicators Research 127(2): 671-690.

Mike, K. (2017): The Intellectual Orders of a Market Economy. Journal of Institutional Economics 13(4): 899-915.

Minarik, P. (2014): Religion and Economic Attitudes in Post-communist Transition. Post-Communist Economies 26(1): 67-88.

Minarik, P. (2019): Religiosity and Economic Attitudes in Post-communist Central Europe: Some Additional Evidence. Social Compass 66(4): 522-542.

Munger, M. (2020): Moral Community and Moral Order: Buchanan's Theory of Obligation. Public Choice 183(3-4): 509-521.

Murphy, R. (2019): The Soft Stuff of Institutional Development: Culture, Cohesion, and Economic Institutions. https://ssrn.com/abstract=3341821, accessed 04/04/2021.

Nelson, R. H. (2012): Is Max Weber Newly Relevant? The Protestant-Catholic Divide in Europe Today. Finnish Journal of Theology 5(November): 420-445.

Péter, L. (2012): Hungary's Long Nineteenth Century: Constitutional and Democratic Traditions in a European Perspective. Leiden and Boston: Brill.

Pitlik, H. - Kouba, L. (2015): Does Social Distrust Always Lead to a Stronger Support for Government Intervention? Public Choice 163(3-4): 355 - 377.

Posner, D. N. (2004): The Political Salience of Cultural Difference: Why Chewas and Tumbukas Are Allies in Zambia and Adversaries in Malawi. American Political Science Review 98(4): 529-545.

Putterman, L. - Weil, D. N. (2010): Post-1500 Population Flows and The Long-Run Determinants of Economic Growth and Inequality. The Quarterly Journal of Economics 125(4): 1627-1682.

Roland, G. (2004): Understanding Institutional Change: Fast-moving and Slow-moving Institutions. Studies in Comparative International Development 38(4): 109-131.

Roland, G. (2020): The Deep Historical Roots of Modern Culture: A Comparative Perspective. Journal of Comparative Economics 48(3): 483-508.

Rubin, J. (2017): Rulers, Religion, and Riches. New York, NY: Cambridge University Press. 
Runst, P. (2013): Post-Socialist Culture and Entrepreneurship. American Journal of Economics and Sociology, 72(3): 593-626.

Runst, P. (2014): Popular Attitudes Toward Market Economic Principles and Institutional Reform in Transition Economies. Review of Social Economy 72(1): 83-115.

Runst, P. (2015): Between Community and Society: Political Attitudes in Transition Countries. In: Grube, L. E - Storr, V. H. (eds): Culture and Economic Action. Cheltenham, UK: Edward Elgar, pp. 318-336.

Siedentop, L. (2014): Inventing the Individual: The Origins of Western Liberalism. Cambridge, MA: Belknap Press of Harvard University Press.

Spolaore, E. - Wacziarg, R. (2009): The Diffusion of Development. Quarterly Journal of Economics 124(2): 469-529.

Spolaore, E. - Wacziarg, R. (2016): Ancestry, Language and Culture. In: Ginsburgh, V. - Weber, S. (eds): The Palgrave Handbook of Economics and Language. London, UK: Palgrave Macmillan, pp. 174-211.

Stein, S. M. (2014): Understanding the Culture of Markets: A Reflection. Review of Austrian Economics 27(4): 489-493.

Storr, V. H. (2013): Understanding the Culture of Markets. London: Routledge.

Storr, V. H. - John, A. (2020): Cultural Considerations within Austrian Economics. Cheltenham, UK: Cambridge University Press.

Tabellini, G. (2010): Culture and Institutions: Economic Development in the Regions of Europe. Journal of the European Economic Association 8(4): 677-716.

Tollison, R. D. (1986): Economists as the Subject of Economic Inquiry. Southern Economic Journal 52(4), 909-922.

Veres, V. (2015): The Minority Identity and the Idea of the 'Unity' of the Nation: The Case of Hungarian Minorities from Romania, Slovakia, Serbia and Ukraine. Identities: Global Studies in Culture and Power 22(1): 88-108.

Weber, M. (1904-5/2001): The Protestant Ethic and the Spirit of Capitalism. London, UK: Routledge.

WVS (2015): World Value Survey 1981-2014 Longitudinal Aggregate v.20150418, 2015. World Values Survey Association. Madrid, Spain: JDSystems Data Archive.

Zweynert, J. - Goldschmidt, N. (2006): The Two Transitions in Central and Eastern Europe as Processes of Institutional Transplantation. Journal of Economic Issues 40(4): 895-918. 


\section{APPENDIX}

Table 4. Questions in EVS/WVS used to construct the dependent variables

\begin{tabular}{|c|c|c|}
\hline & & Question and scale of the answers \\
\hline \multirow[t]{3}{*}{ Trust } & 1 & $\begin{array}{l}\text { Generally speaking, would you say that most people can } \\
\text { be trusted or that you can't be too careful in dealing with } \\
\text { people? } \\
1 \text { - most people can be trusted; } 0 \text { - you can't be too } \\
\text { careful. }\end{array}$ \\
\hline & $2^{*}$ & $\begin{array}{l}\text { Do you think that most people would try to take } \\
\text { advantage of you if they got the chance, or would they try } \\
\text { to be fair? } \\
0 \text { - take advantage of you; . . ; } 1 \text { - be fair. }\end{array}$ \\
\hline & $3^{*}$ & $\begin{array}{l}\text { Would you say that most of the time people try to be } \\
\text { helpful or that they are mostly looking out for } \\
\text { themselves? } \\
0 \text { - look out for themselves; ...; } 1 \text { - try to be helpful. }\end{array}$ \\
\hline \multirow[t]{5}{*}{ Work } & $1^{*}$ & $\begin{array}{l}\text { Here are some aspects of a job that people say are } \\
\text { important. Please look at them and tell me which you } \\
\text { personally think are important in a job: Pleasant people } \\
\text { to work with. } \\
1 \text { - mentioned; } 0 \text { - not mentioned. }\end{array}$ \\
\hline & 2 & $\begin{array}{c}\text { Here are some aspects of a job that people say are } \\
\text { important. Please look at them and tell me which you } \\
\text { personally think are important in a job: An opportunity to } \\
\text { use initiative. } \\
1 \text { - mentioned; } 0 \text { - not mentioned. }\end{array}$ \\
\hline & $3^{*}$ & $\begin{array}{l}\text { Here are some aspects of a job that people say are } \\
\text { important. Please look at them and tell me which you } \\
\text { personally think are important in a job: A useful job for } \\
\text { society. } \\
1 \text { - mentioned; } 0 \text { - not mentioned. }\end{array}$ \\
\hline & $4^{*}$ & $\begin{array}{l}\text { Here are some aspects of a job that people say are } \\
\text { important. Please look at them and tell me which you } \\
\text { personally think are important in a job: Meeting people. } \\
1 \text { - mentioned; } 0 \text { - not mentioned. }\end{array}$ \\
\hline & 5 & $\begin{array}{l}\text { Here are some aspects of a job that people say are } \\
\text { important. Please look at them and tell me which you } \\
\text { personally think are important in a job: A job in which you } \\
\text { feel you can achieve something. } \\
1 \text { - mentioned; } 0 \text { - not mentioned. }\end{array}$ \\
\hline
\end{tabular}

(continued) 
Table 4. Continued

\begin{tabular}{|c|c|c|}
\hline & & Question and scale of the answers \\
\hline & 6 & $\begin{array}{l}\text { Here are some aspects of a job that people say are } \\
\text { important. Please look at them and tell me which you } \\
\text { personally think are important in a job: A responsible job. } \\
1 \text { - mentioned; } 0 \text { - not mentioned. }\end{array}$ \\
\hline & 7 & $\begin{array}{l}\text { Here are some aspects of a job that people say are } \\
\text { important. Please look at them and tell me which you } \\
\text { personally think are important in a job: } A \text { job that is } \\
\text { interesting. } \\
1 \text { - mentioned; } 0 \text { - not mentioned. }\end{array}$ \\
\hline & 8 & $\begin{array}{l}\text { Here are some aspects of a job that people say are } \\
\text { important. Please look at them and tell me which you } \\
\text { personally think are important in a job: A job that meets } \\
\text { one's abilities. } \\
1 \text { - mentioned; } 0 \text { - not mentioned. }\end{array}$ \\
\hline & $9^{*}$ & $\begin{array}{l}\text { Here are some aspects of a job that people say are } \\
\text { important. Please look at them and tell me which you } \\
\text { personally think are important in a job: Learning new } \\
\text { skills. } \\
1 \text { - mentioned; } 0 \text { - not mentioned. }\end{array}$ \\
\hline & $10^{*}$ & $\begin{array}{l}\text { Here are some aspects of a job that people say are } \\
\text { important. Please look at them and tell me which you } \\
\text { personally think are important in a job: Have a say in } \\
\text { important decisions. } \\
1 \text { - mentioned; } 0 \text { - not mentioned. }\end{array}$ \\
\hline & $11^{*}$ & $\begin{array}{l}\text { Here are some aspects of a job that people say are } \\
\text { important. Please look at them and tell me which you } \\
\text { personally think are important in a job: People treated } \\
\text { equally at the workplace. } \\
1 \text { - mentioned; } 0 \text { - not mentioned. }\end{array}$ \\
\hline \multirow[t]{3}{*}{ Gender } & 1 & $\begin{array}{c}\text { Do you agree that when jobs are scarce, men have more } \\
\text { rights to a job than women? } \\
0 \text { - agree; } 0.5 \text { - neither; } 1 \text { - disagree. }\end{array}$ \\
\hline & 2 & $\begin{array}{l}\text { Do you think that a woman has to have children in order } \\
\text { to be fulfilled, or is this not necessary? } \\
0 \text { - need children; } 1 \text { - not necessary. }\end{array}$ \\
\hline & $3^{*}$ & $\begin{array}{l}\text { Do you agree with the following statement: } A \text { job is } \\
\text { alright, but what women really want is a home and } \\
\text { children? } 0 \text { - agree strongly; . . ; } 1 \text { - disagree strongly. }\end{array}$ \\
\hline
\end{tabular}


Table 4. Continued

\begin{tabular}{|c|c|c|}
\hline & & Question and scale of the answers \\
\hline & 4 & $\begin{array}{l}\text { Do you agree with the following statement: Being a } \\
\text { housewife is just as fulfilling as working for pay? } \\
0 \text { - agree strongly; } \ldots ; 1 \text { - disagree strongly. }\end{array}$ \\
\hline \multirow[t]{3}{*}{ Market } & 1 & $\begin{array}{c}\text { How would you place your views on this } 1 \text { to } 10 \text { scale? } \\
0 \text { - The government should take more responsibility to } \\
\text { ensure that everyone is provided for; } \ldots ; 1 \text { - Individuals } \\
\text { should take more responsibility in providing for } \\
\text { themselves. }\end{array}$ \\
\hline & $2^{*}$ & $\begin{array}{l}\text { How would you place your views on this } 1 \text { to } 10 \text { scale? } \\
0 \text { - The state should control firms more effectively; ...; } 1 \\
\text { - The state should give more freedom to firms. }\end{array}$ \\
\hline & 3 & $\begin{array}{l}\text { How would you place your views on this } 1 \text { to } 10 \text { scale? } \\
0 \text { - Government ownership of business and industry } \\
\text { should be increased; ...; } \\
1 \text { - Private ownership of business and industry should be } \\
\text { increased. }\end{array}$ \\
\hline \multirow[t]{5}{*}{ Democracy } & 1 & $\begin{array}{l}\text { Do you agree with the following statement: Democracy } \\
\text { may have problems, but it's better than any other form of } \\
\text { government. } 0 \text { - disagree strongly; . . ; } 1 \text { - agree strongly. }\end{array}$ \\
\hline & 2 & $\begin{array}{l}\text { Do you agree with the following statement: In democracy, } \\
\text { the economic system runs badly. } \\
0 \text { - agree strongly; } \ldots ; 1 \text { - disagree strongly. }\end{array}$ \\
\hline & 3 & $\begin{array}{l}\text { Do you agree with the following statement: Democracies } \\
\text { are indecisive and have too much squabbling. } \\
0 \text { - agree strongly; } \ldots ; 1 \text { - disagree strongly. }\end{array}$ \\
\hline & 4 & $\begin{array}{l}\text { Democracies aren't good at maintaining order. } \\
0 \text { - agree strongly; . . ; } 1 \text { - disagree strongly. }\end{array}$ \\
\hline & 5 & $\begin{array}{l}\text { Would you say that having a democratic political system } \\
\text { is a good way of governing this country? } \\
0 \text { - very bad; . . .; } 1 \text { - very good. }\end{array}$ \\
\hline
\end{tabular}

Source: EVS (2011), WVS (2015), and Beugelsdijk et al. (2019).

${ }^{*}:$ The question was not used in calculating the dependent variable in Table 1 and Section A of Table 2 because it was not asked in waves 3 and 4 of the WVS. All questions are used in Section B of Tables 2 and 3. 
Table 5. Summary statistics of the variables used in the regressions of Table 1

\begin{tabular}{|c|c|c|c|c|c|c|}
\hline & Variable & obs. & Mean & std. dev. & $\min$. & $\max$. \\
\hline \multirow[t]{5}{*}{ Dependent variables } & $\mathrm{d}_{\mathrm{ij}}^{\text {trust }}$ & $4,878,126$ & 0.361 & 0.480 & 0 & 1 \\
\hline & $\mathrm{d}_{\mathrm{ij}}^{\text {work }}$ & $4,878,126$ & 1.420 & 0.538 & 0 & 2.236 \\
\hline & $d^{\text {gender }_{i j}}$ & $4,878,126$ & 0.887 & 0.418 & 0 & 1.732 \\
\hline & $d^{\text {market }}$ ij & $4,878,126$ & 0.567 & 0.296 & 0 & 1.414 \\
\hline & $\mathrm{d}^{\text {democracy }_{i j}}$ & $4,878,126$ & 0.803 & 0.369 & 0 & 2.236 \\
\hline \multirow[t]{7}{*}{ Individual variables } & dist_god & $4,878,126$ & 3.720 & 2.818 & 0 & 9 \\
\hline & dist_sex & $4,878,126$ & 0.500 & 0.500 & 0 & 1 \\
\hline & dist_birthyear & $4,878,126$ & 17.950 & 13.030 & 0 & 74 \\
\hline & dist_education & $4,878,126$ & 2.478 & 1.831 & 0 & 7 \\
\hline & dist_townsize & $4,878,126$ & 2.673 & 1.943 & 0 & 7 \\
\hline & dist_religiouss & $4,878,126$ & 0.434 & 0.496 & 0 & 1 \\
\hline & dist_atheist & $4,878,126$ & 0.072 & 0.259 & 0 & 1 \\
\hline \multirow[t]{14}{*}{ Religion pairs } & cath_cath & $4,878,126$ & 0.074 & 0.262 & 0 & 1 \\
\hline & cath_prot & $4,878,126$ & 0.027 & 0.162 & 0 & 1 \\
\hline & cath_east & $4,878,126$ & 0.290 & 0.454 & 0 & 1 \\
\hline & cath_otherrel & $4,878,126$ & 0.015 & 0.121 & 0 & 1 \\
\hline & cath_nonrel & $4,878,126$ & 0.065 & 0.246 & 0 & 1 \\
\hline & prot_prot & $4,878,126$ & 0.002 & 0.050 & 0 & 1 \\
\hline & prot_east & $4,878,126$ & 0.053 & 0.224 & 0 & 1 \\
\hline & prot_otherrel & $4,878,126$ & 0.003 & 0.052 & 0 & 1 \\
\hline & prot_nonrel & $4,878,126$ & 0.012 & 0.108 & 0 & 1 \\
\hline & east_east & $4,878,126$ & 0.283 & 0.450 & 0 & 1 \\
\hline & east_otherrel & $4,878,126$ & 0.029 & 0.168 & 0 & 1 \\
\hline & east_nonrel & $4,878,126$ & 0.126 & 0.332 & 0 & 1 \\
\hline & otherrel_otherrel & $4,878,126$ & 0.001 & 0.027 & 0 & 1 \\
\hline & otherrel_nonrel & $4,878,126$ & 0.006 & 0.080 & 0 & 1 \\
\hline \multirow[t]{4}{*}{ Country dummies } & d_svk_i & $4,878,126$ & 0.271 & 0.444 & 0 & 1 \\
\hline & d_rou_i & $4,878,126$ & 0.351 & 0.477 & 0 & 1 \\
\hline & d_srb_i & $4,878,126$ & 0.185 & 0.389 & 0 & 1 \\
\hline & d_svk_j & $4,878,126$ & 0.219 & 0.414 & 0 & 1 \\
\hline
\end{tabular}


Table 5. Continued

\begin{tabular}{|c|c|c|c|c|c|c|}
\hline & Variable & obs. & Mean & std. dev. & $\min$. & max. \\
\hline & d_rou_j & $4,878,126$ & 0.095 & 0.293 & 0 & 1 \\
\hline & d_srb_j & $4,878,126$ & 0.675 & 0.468 & 0 & 1 \\
\hline \multirow[t]{2}{*}{ Wave dummies } & wave4_i & $4,878,126$ & 0.039 & 0.193 & 0 & 1 \\
\hline & wave4_j & $4,878,126$ & 0.355 & 0.478 & 0 & 1 \\
\hline \multirow[t]{2}{*}{ Same country and ethnicity } & samecountry & $4,878,126$ & 0.305 & 0.461 & 0 & 1 \\
\hline & sameethnicity & $4,878,126$ & 0.284 & 0.451 & 0 & 1 \\
\hline \multirow[t]{23}{*}{ Ethnicity dummies } & Albanian_i & $4,878,126$ & 0.001 & 0.030 & 0 & 1 \\
\hline & Bosnian_i & $4,878,126$ & 0.001 & 0.026 & 0 & 1 \\
\hline & Czech_i & $4,878,126$ & 0.000 & 0.018 & 0 & 1 \\
\hline & English_i & $4,878,126$ & 0.000 & 0.017 & 0 & 1 \\
\hline & German_i & $4,878,126$ & 0.002 & 0.040 & 0 & 1 \\
\hline & Montenegrin_i & $4,878,126$ & 0.001 & 0.033 & 0 & 1 \\
\hline & Romanian_i & $4,878,126$ & 0.336 & 0.472 & 0 & 1 \\
\hline & Romany_i & $4,878,126$ & 0.002 & 0.039 & 0 & 1 \\
\hline & Serbian_i & $4,878,126$ & 0.176 & 0.381 & 0 & 1 \\
\hline & Slovak_i & $4,878,126$ & 0.249 & 0.433 & 0 & 1 \\
\hline & Ukrainian_i & $4,878,126$ & 0.002 & 0.043 & 0 & 1 \\
\hline & Other_i & $4,878,126$ & 0.001 & 0.027 & 0 & 1 \\
\hline & More_i & $4,878,126$ & 0.000 & 0.022 & 0 & 1 \\
\hline & White_i & $4,878,126$ & 0.002 & 0.050 & 0 & 1 \\
\hline & Albanian_j & $4,878,126$ & 0.005 & 0.070 & 0 & 1 \\
\hline & Bosnian_j & $4,878,126$ & 0.003 & 0.056 & 0 & 1 \\
\hline & Czech_j & $4,878,126$ & 0.000 & 0.017 & 0 & 1 \\
\hline & English_j & $4,878,126$ & 0.000 & 0.019 & 0 & 1 \\
\hline & German_j & $4,878,126$ & 0.000 & 0.018 & 0 & 1 \\
\hline & Montenegrin_j & $4,878,126$ & 0.004 & 0.063 & 0 & 1 \\
\hline & Romanian_j & $4,878,126$ & 0.091 & 0.288 & 0 & 1 \\
\hline & Romany_j & $4,878,126$ & 0.001 & 0.032 & 0 & 1 \\
\hline & Serbian_j & $4,878,126$ & 0.628 & 0.483 & 0 & 1 \\
\hline
\end{tabular}

(continued) 
Table 5. Continued

\begin{tabular}{|c|c|c|c|c|c|c|}
\hline & Variable & obs. & Mean & std. dev. & min. & max. \\
\hline & Slovak_j & $4,878,126$ & 0.201 & 0.401 & 0 & 1 \\
\cline { 2 - 7 } & Ukrainian_j & $4,878,126$ & 0.001 & 0.037 & 0 & 1 \\
\cline { 2 - 7 } & Other_j & $4,878,126$ & 0.011 & 0.103 & 0 & 1 \\
\cline { 2 - 7 } & More_j & $4,878,126$ & 0.005 & 0.072 & 0 & 1 \\
\cline { 2 - 7 } & White_j & $4,878,126$ & 0.003 & 0.051 & 0 & 1 \\
\hline
\end{tabular}

Open Access. This is an open-access article distributed under the terms of the Creative Commons Attribution 4.0 International License (https://creativecommons.org/licenses/by/4.0/), which permits unrestricted use, distribution, and reproduction in any medium, provided the original author and source are credited, a link to the CC License is provided, and changes - if any - are indicated. (SID_1) 